Final Draft of the original manuscript:

Wagner, D. (2008) Microbial Communities and Processes in Arctic Permafrost Environments. In: P. Dion and C.S. Nautiyal (eds.), Microbiology of Extreme Soils. Soil Biology 13, Springer Berlin, pp 133-154.

ISSN 1613-3382 (springer.com) 


\title{
7. Microbial Communities and Processes in Arctic Permafrost Environments
}

\section{Dirk Wagner}

Alfred Wegener Institute for Polar and Marine Research, Research Unit

Potsdam, Telegrafenberg A45, 14473 Potsdam, Germany

Phone: +49 331288 2159, FAX: +49 331288 2137,

Email: Dirk.Wagner@awi.de

\begin{abstract}
In polar regions huge layers of frozen ground are formed - termed permafrost - which covers more than $25 \%$ of the land mass and significant parts of the coastal sea shelfs. Permafrost habitats are controlled by extreme climate and terrain conditions. Particularly, the seasonal freezing and thawing in the upper active layer of permafrost leads to distinct gradients in temperature and geochemistry. Due to the harsh living conditions, microorganisms in permafrost environments have to survive extremely cold temperatures, freeze-thaw cycles, desiccation and starvation under long-lasting background radiation over geological time scales. Although, permafrost microorganisms remains relatively unexplored, recent findings show that microbial communities in this extreme environment are composed by members of all three domains of life (Archaea, Bacteria, Eukarya), with a total biomass comparable to temperate soil ecosystems. This chapter describes the environmental conditions of permafrost and reviews recent studies on microbial processes and diversity in permafrost affected soils as well as the role and significance of microbial communities on the global biogeochemical cycles.
\end{abstract}

\subsection{Introduction}

The Arctic plays a key role in Earth's climate system as global warming is predicted to be most pronounced at high latitudes and because one third of the global carbon pool is stored in ecosystems of the northern latitudes. Global warming will have important implications for the functional diversity of microbial communities in these systems. It is likely that temperature increases in high latitudes may stimulate microbial activity and carbon decomposition in Arctic environments and are accelerating climate change through the increase of trace gas release (Melillo et al. 2002, Zimov et al. 2006, see Chap. 8 of this issue).

In polar regions huge layers of frozen ground are formed - termed permafrost - which covers more than $25 \%$ of the land mass (Zhang et al. 1999) and significant parts of the coastal sea shelfs (Romanovskii et al. 2005, Fig. 7.1). Permafrost can extend hundreds of meters to more than $1000 \mathrm{~m}$ into the subsurface (Williams and Smith 1989). This environment is controlled by extreme climate and terrain conditions. Particularly, the seasonal freezing and thawing leads to distinct gradients 
in temperature and geochemistry in the upper active layer of permafrost. As it was thought that these conditions were hostile for life, permafrost was considered as uninhabitable also for microorganisms. However, from recent findings we know that microbial communities in permafrost environments are composed by members of all three domains of life (Archaea, Bacteria and Eukarya), with a total biomass comparable to temperate soil ecosystems (Wagner et al. 2005).

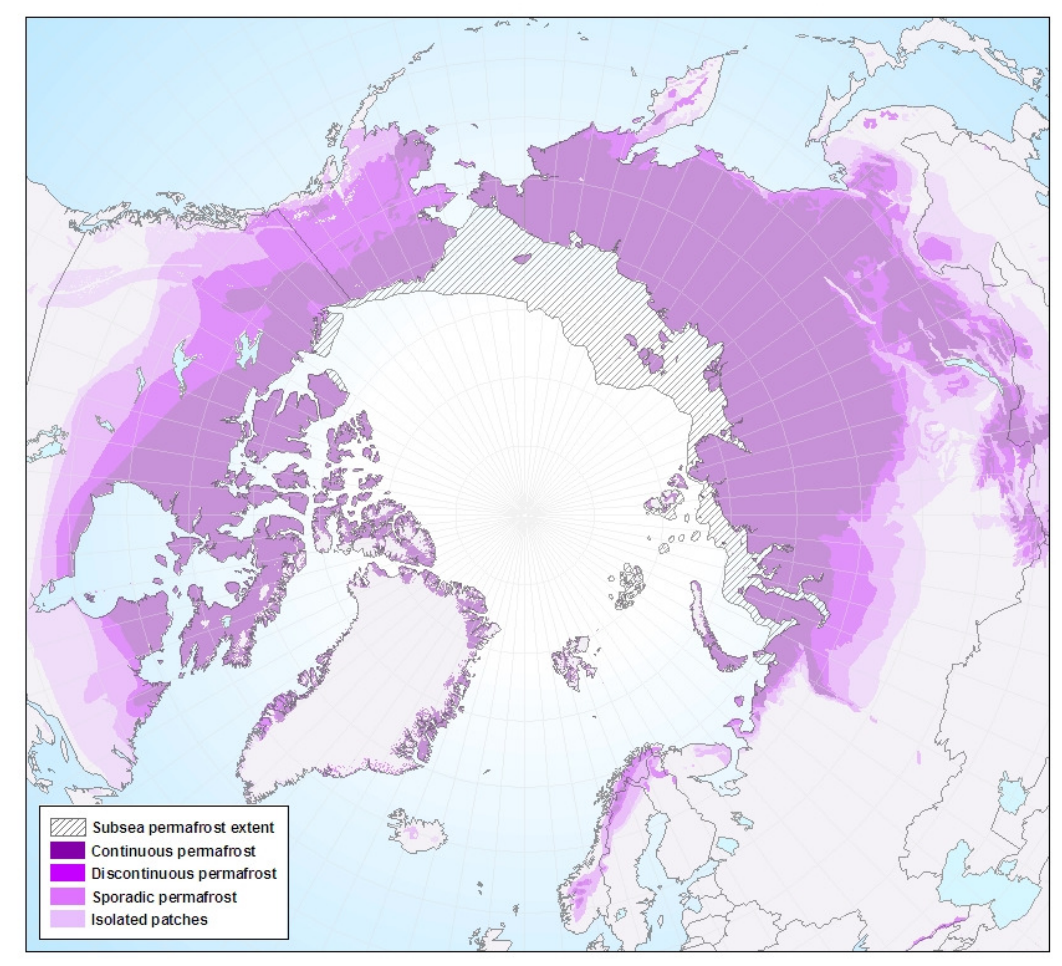

Figure 7.1: Terrestrial and submarine permafrost distribution in the northern hemisphere (International Permafrost Association Standing Committee on Data Information and Communication 2003).

The permafrost microbial communities have to overcome the combined action of extremely cold temperature, freeze-thawing cycles, desiccation and starvation (Gilichinsky and Wagener 1994, Morozova and Wagner 2007). Recent studies indicated that microorganisms do not only survive under permafrost conditions, but can be also metabolic active (Rivkina et al. 2004, Wagner et al. 2007). Allthough, modern molecular-ecological studies of diversity and community structure in permafrost environments are still rare (e.g. Rivkina et al. 2000, Wartiainen et al. 2003, Colwell et al. 1999, Vishnivetskaya et al. 2006, Ganzert et al. 2007, Steven et al. 2007), a diverse range of microorganisms have been discovered in the different ecosystems (Shi et al. 1997, Kobabe et al. 2004, Wagner et al. 2005). Although microbial metabolism has been rather well studied in temperate environments, little is known about the role of microbial diversity for the functioning and stability of the Arctic ecosystem, about the carbon dynamics controlled by microorganisms and 
about the reaction of these microorganisms to changing environmental conditions in high latitudes.

Apart from the global relevance of permafrost as a large carbon reservoir, this extreme environment is also of particular interest in the scope of astrobiological research as an analogue for extraterrestrial permafrost habitats, which is a common phenomenon in our solar system. Since the current ESA mission Mars Express determined for the first time methane in the Martian atmosphere (Formisano 2004), recent studies focused on methanogenic archaea from permafrost environments as potential candidates for life on Mars (Wagner et al. 2001, Morozova et al. 2007, see Chap. 10 of this issue).

This review describes the environmental conditions of permafrost, the microbial communities, their function (so far it is known) and their role and significance in the biogeochemical cycles.

\subsection{The Permafrost Environment}

Permafrost is defined as the thermal condition, in which soils, sediments and rocks remain at or below $0{ }^{\circ} \mathrm{C}$ for two or more years in succession (van Everdingen 2005). Arctic permafrost regions are characterized by low mean annual air temperatures, a low mean annual precipitation (Table 7.1) and poor to missing vegetation. During the relatively short period of arctic summer only the surface zone (few decimeter) of permafrost sediments thaws, called the active layer. Active layer depths ranged from a few centimeters in the high Arctic to more than $2 \mathrm{~m}$ in subarctic regions. Permafrost can be cemented by ice, which is typical for Arctic regions, or, in the case of insufficient interstitial water, may be dry like the Antarctic polar deserts or rocky areas.

The permafrost environment can be divided into three temperature-depth layers, characterized by different living conditions. The active layer with an extreme temperature regime from about +15 to $-35^{\circ} \mathrm{C}$ depending on air temperature fluctuations; the upper, perennially frozen permafrost sediments (10-20m thickness) with smaller seasonal temperature variation of about 0 to $-15^{\circ} \mathrm{C}$ above the zero annual amplitude; and the deeper permafrost sediments, which are characterized by a stable temperature regime of about -5 to $-10^{\circ} \mathrm{C}$ (French 1996). The boundary between the active layer and the perennially frozen ground is called permafrost table, which acts as a physical and chemical barrier. Intensive physico-chemical processes under extreme conditions take place in the active layer and upper permafrost sediments (Ostroumov 2004). The deeper permafrost layers are characterized by living conditions which have been stable for long periods of time and where microbial processes are limited (French 1996). 
Amongst the specific stratigraphy of permafrost, this environment is characterized by patterned ground formation and by different cryogenic structures such as ice wedges, taliks and cryopegs (Fig. 7.2), which are defined by their thermal conditions. The large differences between summer and winter temperature in permafrost environments for instance leads to the formation of typical patterned grounds (e.g. sorted circle and high- and low-centered polygons) with a prominent mircrorelief (Fig. $7.3 \mathrm{a}-\mathrm{c}$ ). The development of these structures is often related to the processes of ground ice formation. The term ground ice describes all types of ice in permafrost deposits, ranging from poor ice crystals to massive horizontal layers of ice with a thickness of several decameter.

Table 7.1: Climate data for selected localities in circum-arctic permafrost environments

\begin{tabular}{lccccc}
\hline \multicolumn{1}{c}{ Locality } & Coordinates & $\begin{array}{c}\text { Mean annual } \\
\text { temperature } \\
{\left[{ }^{\circ} \mathrm{C}\right]}\end{array}$ & $\begin{array}{c}\text { Minimum/ } \\
\text { maximum } \\
\text { temperature } \\
{\left[{ }^{\circ} \mathrm{C}\right]}\end{array}$ & $\begin{array}{c}\text { Total } \\
\text { precipitation } \\
{[\mathrm{mm}]}\end{array}$ & Reference \\
\hline $\begin{array}{l}\text { Green } \\
\begin{array}{l}\text { Harbour, } \\
\text { Spitzbergen }\end{array}\end{array}$ & $78^{\circ} \mathrm{N}, 15^{\circ} \mathrm{E}$ & -8 & $-19 \ldots+6$ & 370 & French, 1996 \\
\hline $\begin{array}{l}\text { Severnay } \\
\begin{array}{l}\text { Zemlya, } \\
\text { Krasnoyarsk }\end{array}\end{array}$ & $79^{\circ} \mathrm{N}, 91^{\circ} \mathrm{E}$ & -14 & $-45 \ldots+6$ & 97 & Orvig, 1970 \\
\hline $\begin{array}{l}\text { Lena Delta, } \\
\text { Yakutsk }\end{array}$ & $73^{\circ} \mathrm{N}, 126^{\circ} \mathrm{E}$ & -15 & $-48 \ldots+18$ & 320 & ROSHYDROMET, \\
\hline $\begin{array}{l}\text { Lake } \\
\text { Elgygytgyn, } \\
\text { Chukotka }\end{array}$ & $67^{\circ} \mathrm{N}, 172^{\circ} \mathrm{E}$ & -10 & $-40 \ldots+26$ & 178 & $\begin{array}{l}\text { Nolan \& Brigham- } \\
\text { Grette, } 2007\end{array}$ \\
\hline $\begin{array}{l}\text { Dawson City, } \\
\text { Canada }\end{array}$ & $64^{\circ} \mathrm{N}, 139^{\circ} \mathrm{W}$ & -5 & $-31 \ldots+14$ & 343 & French, 1996 \\
\hline $\begin{array}{l}\text { Sachs } \\
\text { Harbour, } \\
\text { Canada }\end{array}$ & $71^{\circ} \mathrm{N}, 125^{\circ} \mathrm{W}$ & -14 & $-29 \ldots+5$ & 93 & French, 1996 \\
\hline
\end{tabular}

Ice wedges occurred typically in tundra environments with polygonal patterned grounds. In the cold winter season thermal contraction cracks form polygonal nets. These cracks have been filled with snow melt water at the beginning of spring. Repeated cracking, filling with water and freezing can produce low-centred polygonal microrelief with ice wedges of several meters in width and two to three decameters in depth over geological times of ten thousand years (Fig. 7.3 e, Washburn 1978). Pleistocene ice-rich erosional remains of such a polygonal landscape is called ice complex (Yedoma; Fig. 7.3 f). An unfrozen sediment layer or body in the perennially frozen ground, mostly below water bodies, is called talik, which occurred due to local anomalies in thermal, hydrological, hydrogeological, or hydrochemical conditions (van Everdingen 2005). Cryopegs (overcooled water brine lenses) are defined as a layer of unfrozen ground that is perennially cryotic, forming part of the permafrost (van Everdingen 2005). Freezing of cryopegs is prevented by freezing-point 
depression due to the high salt content of the pore water (140-300 $\mathrm{g} \mathrm{I}^{-1}$, Gilichinsky et al. 2005).

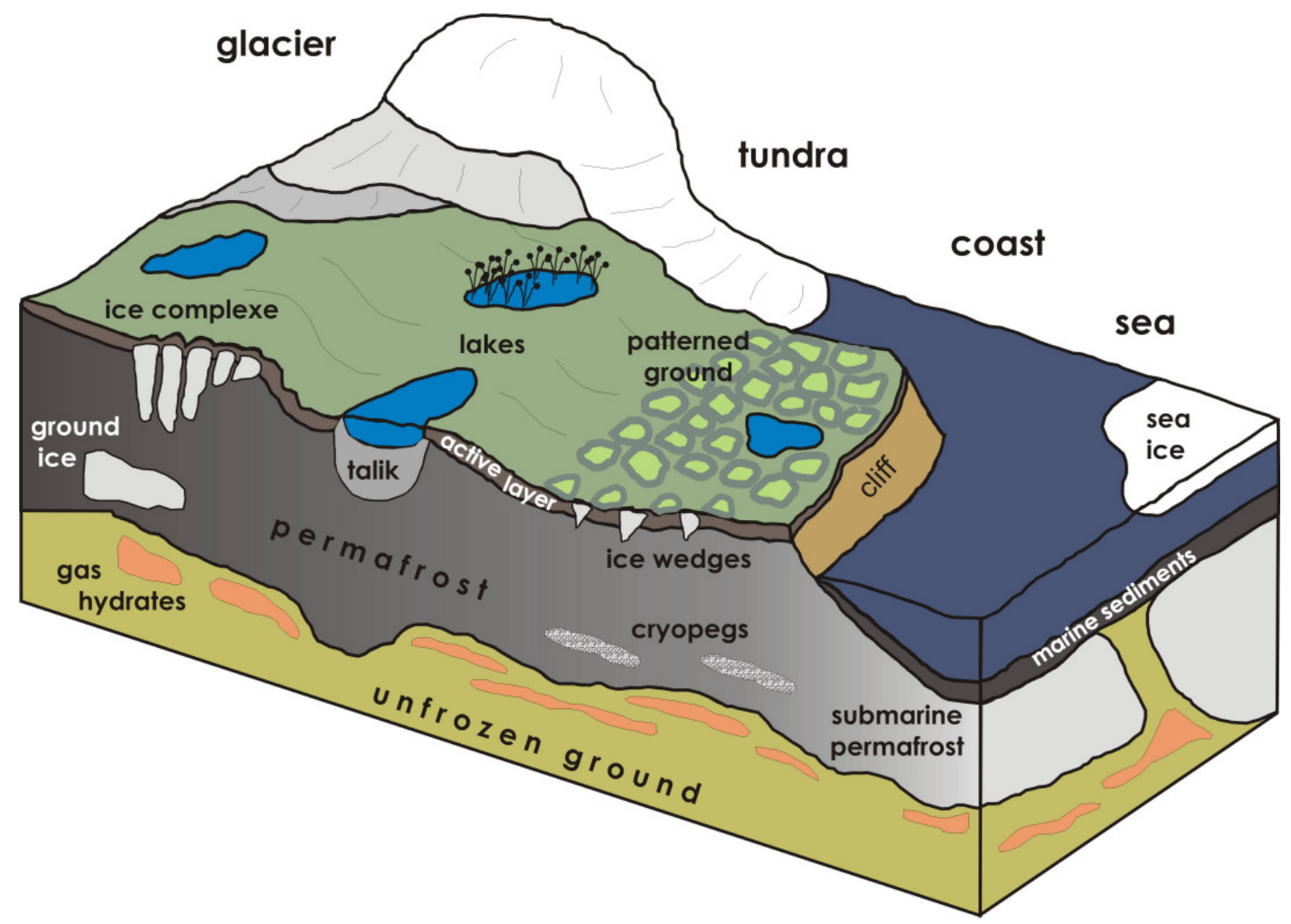

Figure 7.2: Block diagram of an Arctic permafrost environment showing the different landscape units (glacier, tundra, coast and sea) with the potential cryogenic features (ice complexes and wedges, massive ground ice, taliks, cryopegs), differentiated by their thermal regime.

It is well-known for some time that the shallow shelfs of the Arctic coastal seas are underlined by submarine permafrost (Fig. 7.1 and 7.2), which was formed during the Holocene sea level rise by flooding of the formerly terrestrial permafrost (Romanovskii et al. 2005). The flooding of the cold terrestrial permafrost $\left(-5\right.$ to $\left.-15^{\circ} \mathrm{C}\right)$ with relatively warm saline sea water $\left(-0.5\right.$ to $\left.-2^{\circ} \mathrm{C}\right)$ changed the system profoundly and resulted in a warming of the permafrost (Overduin 2007).

Permafrost soils (cryosols) have been developed in the upper zone of the cryolithosphere (active layer and upper permafrost sediments) where the temperature ranges from $-50 \mathrm{C}$ to $+30 \mathrm{C}$ (Yershov 1998). Therefore, permafrost soils are mainly formed by cryopedogenesis, which include freezing and thawing, frost stirring, mounding, fissuring and solifluction. The repeating cycles of freezing and thawing leads to cryoturbation features (frost churning) that includes irregular, broken or 
involutedly horizons (Fig. $7.3 \mathrm{~d}$ ) and an enrichment of organic matter and other inorganic compounds, especially along the top of the permafrost table (Van VlietLanoë 1991, Bockheim et al. 1999). As a result of cryopedogenesis many permafrost soils are influenced by a strong micro-relief causes small-scale variations in soil types (Fig. $7.3 \mathrm{~d}$ and g) and vegetation characteristics as well as in the microclimatic conditions of the habitats. This affects the abundance, processes and diversity of microbial communities in permafrost environments. Table 7.2 summarizes the physiochemical properties exemplarily for permafrost soils of the dry rim part of a low-centered polygon from the Lena Delta, Siberia.

Table 7.2: Selected physiochemical properties of a permafrost soil (Glacic Aquiturbel) of the Lena Delta, northeast Siberia (modified according to Wagner et al. 2005)

\begin{tabular}{lcccccccccc}
\hline Horizon & $\begin{array}{c}\text { Depth } \\
{[\mathbf{c m}]}\end{array}$ & $\begin{array}{c}\mathbf{T} \\
{\left[{ }^{\circ} \mathbf{C}\right]}\end{array}$ & $\mathbf{p H}$ & $\begin{array}{c}\text { TOC } \\
{[\%]}\end{array}$ & $\begin{array}{c}\mathbf{T N} \\
{[\%]}\end{array}$ & $\begin{array}{c}\mathbf{D O C} \\
{\left[\mathbf{m g ~ l}^{-1}\right]}\end{array}$ & $\begin{array}{c}\mathbf{C H}_{4} \\
\left.\mathbf{\mu m o l ~}^{-1}\right]\end{array}$ & $\begin{array}{c}\text { Sand } \\
{[\%]}\end{array}$ & $\begin{array}{c}\text { Silt } \\
{[\%]}\end{array}$ & $\begin{array}{c}\text { Clay } \\
{[\%]}\end{array}$ \\
\hline Ajj & $0-5$ & 6.4 & n.d. & 2.1 & 0.12 & 7.3 & 0.4 & 85.7 & 10.4 & 3.9 \\
\hline Bjjg1 & $5-12$ & 5.0 & n.d. & 2.0 & 0.11 & 7.1 & 0.3 & 74.3 & 20.6 & 5.0 \\
\hline Bjjg2 & $12-20$ & 4.0 & n.d. & 2.4 & 0.14 & 9.0 & 35.3 & 68.0 & 25.8 & 6.3 \\
\hline & $20-27$ & 3.4 & 7.9 & 3.0 & 0.09 & 7.3 & 65.8 & 63.7 & 30.3 & 6.0 \\
\hline & $27-35$ & 2.4 & 6.7 & 2.4 & 0.07 & 4.0 & 153.5 & 56.5 & 34.5 & 9.1 \\
\hline Bjjg3 & $35-42$ & 1.7 & 6.8 & 2.7 & 0.15 & 8.7 & 224.7 & 59.3 & 34.0 & 6.7 \\
\hline & $42-49$ & 1.0 & n.d. & 3.3 & 0.18 & 17.3 & 478.7 & 43.7 & 43.8 & 12.5 \\
\hline
\end{tabular}

Horizon nomenclature according to Soil Survey Staff (1998); $T=$ temperature; TOC = total organic carbon; $T N=$ total nitrogen; $D O C=$ dissolved organic carbon

The seasonal variation of soil temperature also influences the availability of pore water. The presence of unfrozen water is an essential bio-physical requirement for the survival of microorganisms in permafrost. Temperatures below zero stand for an increasing loss of free water. At the same time, freezing of water leads to an increase of salt content in the remaining pore solution. However, in clayey permafrost soils liquid water was found at temperatures up to $-60^{\circ} \mathrm{C}$ (Ananyan 1970). The most important biological feature of this water is the possible transfer of ions and nutrients (Ostroumov and Siegert 1996).

Permafrost ecosystems are therefore extremely heterogeneous in nature, depending on the regional climatic conditions, which provide harsh and strongly fluctuating conditions to their inhabitants. In these habitats, the extraordinarily high content of solid components randomly intermixed with gaseous and liquid components hampers the movement of microorganisms, the mixing of substrates and physical interaction with other organisms. This stimulates the formation of spatially separated microcolonies, which are subject to location-based adaptation and microevolutionary processes. 

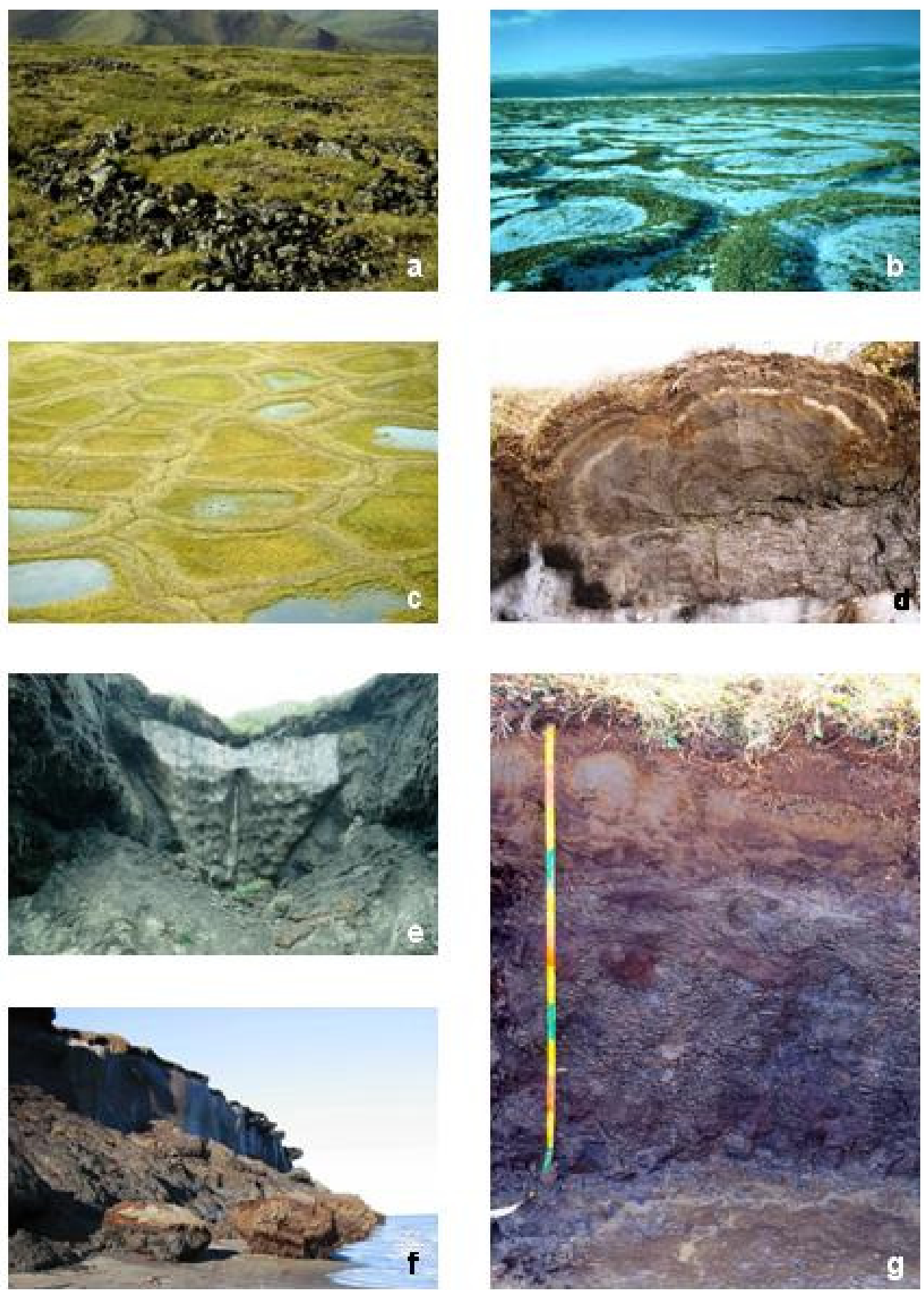

Figure 7.3: Patterned grounds, cryogenic structures and permafrost soils of Arctic polar regions: a. sorted nets, Dawson City, Canada (photo E.-M. Pfeiffer, University of Hamburg); b. sorted circle, Spitsbergen (photo J. Boike, AWI); c. low-centered polygons, Lena Delta, Siberia (photo D. Wagner, AWI); d. permafrost soil (Glacic Aquiturbel) of the polygon rim, Lena Delta, Siberia (photo L. Kutzbach, University of Greifswald); g. permafrost soils (Ruptic-Histic Aquiturbel) of an ice complex area, Lena Delta, Siberia (photo D. Wagner, AWI); e. ice-wedge, Lena Delta, Siberia (photo D. Wagner, AWI) and f. ice complex, Lena Delta, Siberia (photo V. Rachold, IASC). 


\subsection{Permafrost Microbiota}

The first report on viable microorganisms in permafrost was given in 1911 by Omelyansky. This pioneering investigation was followed by a number of studies revealed significant cell counts and various types of microorganisms, including bacteria, yeasts, fungi and protozoa, within the soils of the active layer and the perennially frozen ground (Kris 1940, James and Southerland 1942, Boyd 1958, Boyd and Boyd 1964). Since that time, a number of investigations on microbial abundance and physiology within different circum-arctic environments had been undertaken (e.g. Zvyagintsev et al. 1985, Khlebnikova et al. 1990, Rivkina et al. 2000, Kobabe et al. 2004, Gilichinsky et al. 2005, Zak and Kling 2006, Liebner and Wagner 2007).

With classical isolation strategies microorganisms from the most important physiological groups could be identified including aerobic and anaerobic heterotrophs, methane oxidizers, nitrifying and nitrogen fixing bacteria, sulfate and iron reducers, acetogens and methanogens. The dominant microbial genera are Acetobacterium, Acinetobacter, Arthrobacter, Bacillus, Cellulomonas, Flavobacterium, Methanosarcina, Methylobacter, Micrococcus, Nitrobacter, Nitrosomonas, Pseudomonas, Rhodococcus, and Streptomyces (e.g. Gilichinsky et al. 1995, Kotsyurbenko et al. 1995, Omelchenko et al. 1996, Shi et al. 1997, Simankova et al. 2000, Suzuki et al. 2001, Wartiainen et al. 2006a). Total microbial counts obtained for permafrost soils gave high numbers of microorganisms in the range from $10^{8}$ to $10^{9}$ cells $\mathrm{g}^{-1}$ soil (Kobabe et al. 2004) and for the perennially frozen ground between $10^{3}$ and $10^{8}$ cells $\mathrm{g}^{-1}$ sediment (Rivkina et al. 1998).

However, it is notoriously difficult to obtain a wide diversity of microorganisms from environmental samples in culture, especially from low temperature habitats, and the biogeochemical roles of Bacteria, Archaea and Fungi have consequently been studied using black-box techniques such as epifluorescence direct counts, DNA and protein synthesis rates, enzyme activity, and a host of other methods that are inherently blind to variations in community composition (e.g. Vorobyova et al. 1997, Spirina and Fedorov-Davydov 1998, Bakermans et al. 2003, Šantrůčková et al. 2003, Colwell et al. 1999, Liebner and Wagner 2007, Panikov and Sizova 2007). Much of what is now known of the diversity of environmental microbial diversity is based on distinguishing among different organisms, as represented by their extracted and polymerase chain reaction (PCR)-amplified nucleic acids or their lipid composition, without actually culturing them or having any direct knowledge of their morphology, physiology or ecology. However, modern molecular-ecological studies of diversity and community structure in permafrost environments are still rare (e.g. Zhou et al. 1997, Høj et al. 2005, Neufeld and Mohn 2005, Ganzert et al. 2007, Steven et al. 2007). 
Both with the fluorescence in situ hybridization (FISH) and with DNA based investigations all relevant groups of microorganisms $(\alpha-, \beta-, \gamma$ - and $\delta$-subclasses of Proteobacteria, Cytophaga-Flavobacterium cluster, gram-positive Bacteria with low and high GC content and Archaea) could be detected with high cell numbers in the active layer and in the frozen ground of permafrost (Shi et al. 1997, Zhou et al. 1997, Kobabe et al. 2004). Despite all differences in the requirements of the specific groups, which influence their abundances in the soils, the total diversity and quantity of active cells was strongly related to the content and quality of organic matter (Kobabe et al. 2004; Wagner et al., 2005). Nevertheless, in spite of the harsh environmental conditions in the deeper horizons of the active layer close to the permafrost table, there is evidence for high amount of cells $\left(4 \times 10^{7}\right.$ cells $^{-1}$ soil) with at least minimal activity (Kobabe et al. 2004). Detailed bacterial 16S rDNA clone library analyses of a polygonal tundra from the Lena Delta (northern Siberia) revealed a distinct variability of the main phyla (Actinobacteria, Bacteroidetes, Chloroflexi, Firmicutes, Gemmatimonadetes, Planctomycetes, Proteobacteria and Verrucomicrobia) within the soil of the polygon rim, while the community composition in the center soil is more homogenous depending on the small-scale variability of environmental conditions (S. Liebner pers. communication). Particularly, the communities are dominated by Bacteroidetes, Actinobacteria, Proteobacteria and Firmicutes (in the sequence with decreasingly portions) with a distinct shift following the vertical temperature profile. Another study carried out in Northeast Siberia showed that the $\alpha$ - and $\delta$-subclasses of the Proteobacteria dominated the microbial community with a portion of about $50 \%$ (Zhou et al. 1997). Microbial community analyses of the frozen ground studied on Ellesmere Island, Canada showed a similar composition compared with the active layer, but dominating phyla were Actinobacteria- and Proteobacteria-related sequences (Steven et al. 2007). The archaeal community in this study was composed of $61 \%$ Euryarchaeota and $39 \%$ Crenarchaeota, suggesting the presence of a diverse archaeal population. In ancient permafrost sediments from Northeast Siberia the following major groups were found: Actinomycetales (Arthrobacter and Microbacteriaceae), Actinobacteria, Bacteroidetes (Flavobacterium), Firmicutes (Exiguobacterium and Planomicrobium), $\alpha-$ Proteobacteria (Sphingomonas) and Y-Proteobacteria (Psychrobacter and Xanthomonadaceae; Vishnivetskaya et al. 2006). In all the studies a distinct part of the microbial community belonged to so far unclassified microorganisms, which indicates the existence of large unknown communities in permafrost environments. Thus, the physiology and function of these presumably dominant microorganisms are still unknown as well.

The best investigated microorganisms in permafrost environments are methanogenic archaea and methane oxidizing bacteria as the main player in the Arctic methane cycle and in consequence of their significance for the global methane budget. 

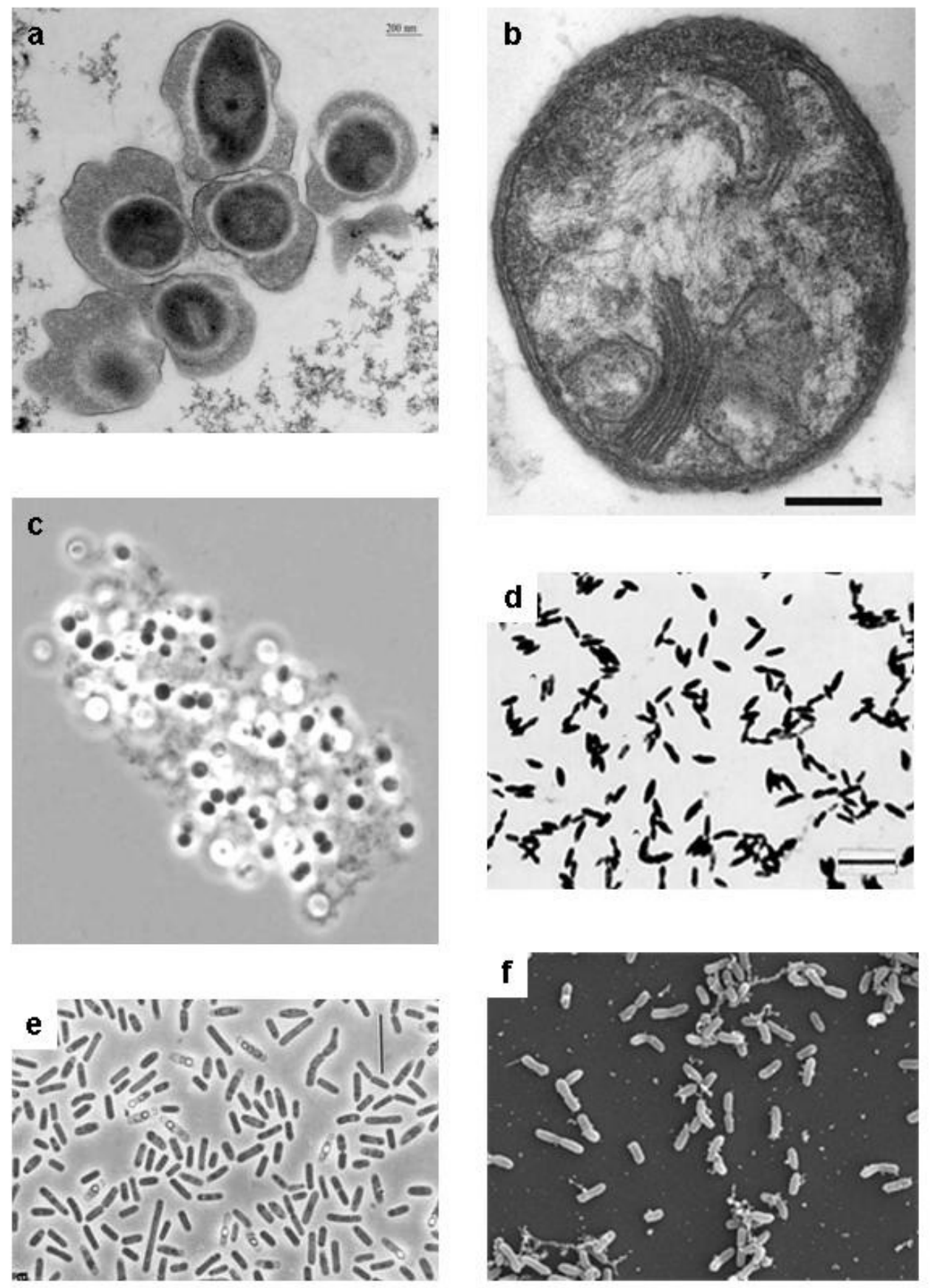

Figure 7.4: Selected microorganisms (Bacteria, Archaea) isolated from different permafrost environments: a. Candidatus Nitrotoga arctica (with courtesy of E. Spieck and T. Sanders, University Hamburg); b. Methylobacter tundripaludum (Wartiainen et al., 2006a); c. Methanosarcina sp. SMA-21 (D. Wagner and D. Morozova, AWI); d. Acetobacterium tundrae (Simankova et al. 2000); e. Clostridium algoriphilum (Shcherbakova et al. 2005) and f. Psychrobacter sp. 273-4 (Vishnivetskaya et al. 2000). 
The microbial methane production (methanogenesis) is one of the most prominent microbiological processes during the anaerobic decomposition of organic matter. Methanogenesis is solely driven by a small group of strictly anaerobic organisms called methanogenic archaea, which belong to the kingdom Euryarchaeota (Garcia et al. 2000).

The highest cell counts of methanogenic archaea were detected in the active layer of permafrost with numbers up to $3 \times 10^{8} \mathrm{cells}^{-1}$ soil (Kobabe et al. 2004). The portion of methanogens of the total cell counts varied from $0.5 \%$ to $22.4 \%$. Phylogenetic analyses revealed a distinct diversity of methanogens in the active layer, with species belonging to the families Methanobacteriaceae, Methanomicrobiaceae, Methanosarcinaceae, and Methanosaetaceae (Høj et al. 2005, Metje and Frenzel 2007, Ganzert et al. 2007). In addition sequences affiliated with the euryarchaeotal Rice Cluster II and V (Hales et al. 1996, Grosskopf et al. 1998, Ramakrishnan et al. 2001) as well as with Group I.3b of the uncultured Crenarchaeota (non-methanogenic archaea; Ochsenreiter et al. 2003). There were no restrictions of the detected families to specific depths of the soil profiles. Environmental sequences from the Laptev Sea coast form four specific permafrost clusters (Ganzert et al. 2007). Permafrost Cluster I was recovered mainly from cold horizons $\left(<4{ }^{\circ} \mathrm{C}\right)$ of the active layer and related to Methanosarcinacea. Permafrost Clusters II and III related to Methanomicrobiales and Permafrost Cluster IV related to Rice Cluster II. It was hypothesized by the authors that the specific permafrost clusters are formed by methanogenic archaea characterized by a specific physiological potential to survive under harsh environmental conditions. The phylogenetic affiliation of recovered sequences indicated a potential of both hydrogenotrophic and acetoclastic methanogenesis in permafrost soils.

Methanosarcina spec. SMA-21 closely related to Methanosarcina mazei was recently isolated from a Siberian permafrost soil in the Lena Delta. The organism grows well at $28^{\circ} \mathrm{C}$ and slowly at low temperatures $\left(4^{\circ} \mathrm{C}\right.$ and $\left.10^{\circ} \mathrm{C}\right)$ with $\mathrm{H}_{2} / \mathrm{CO}_{2}$ $(80: 20, \mathrm{v} / \mathrm{v}$, pressurised $150 \mathrm{kPa})$ as a substrate. The cells grow as cocci, with a diameter of 1-2 $\mu \mathrm{m}$. Cell aggregates were regularly observed (Fig. 7.4c). Methanosarcina SMA-21 is characterized by an extreme tolerance against extreme low temperatures $\left(-78.5^{\circ} \mathrm{C}\right)$, high salinity, starvation, desiccation and oxygen exposure (Morozova and Wagner 2007). Furthermore, this archaeon survived three weeks under simulated thermo-physical Martian conditions (Morozova et al. 2007).

The biological oxidation of methane by methane oxidizing (methanotrophic) bacteria, which represent very specialized Proteobacteria, is the only sink for methane in permafrost habitats (Trotsenko and Khmelenina 2005). Methanotrophic bacteria are common in almost all environments, where they can survive under unfavourable living conditions by the formation of spores. 
Up to $2 \times 10^{8}$ cells of methane oxidizing bacteria $\mathrm{g}^{-1}$ soil were detected by fluorescence in situ hybridization in the active layer of permafrost soils (Liebner and Wagner 2007). Most horizons of the soils were dominated by type I methanotrophic bacteria. Only in samples close to the permafrost table type II were more abundant than type I methanotrophs. However, based on phospholipid fatty acid (PLFA) concentrations and stable isotope probing the community growing at low in situ temperatures was dominated by type I methanotrophs (C. Knoblauch pers. communication). This was also confirmed by phylogenetic analyses of methanotrophic bacteria in Arctic wetland soils of Svalbard indicated more type I than type II methanotrophs. However, the analyses revealed the two genera Methylobacter (type I) and Methylosinus (type II) in all studied localities (Wartiainen et al. 2003). Phospholipid fatty acid analyses revealed the signature PLFA 18:1 $\Delta$ cis 10 for the two methanotrophic genera Methylosinus and Methylocystis of the a-Proteobacteria only in the dryer sites of polygonal tundra. In contrast, the PLFA 16:1 $\Delta$ cis8 indicative for the genera Methylomonas, Methylomicrobium, Methylosarcina and Methylosphaera were detected in all sites of the polygonal tundra in the Lena Delta (Wagner et al. 2005).

Methylobacter psychrophilus isolated from a Siberian tundra soil represent a cold-loving methane oxidizing bacteria belong to type I species (Omelchenko et al. 1996). Recently two new species of methanotrophs were isolated from an Arctic wetland soil on Svalbard. Methylobacter tundripaludum (Fig. 7.4b) belong to type I species. The gram-negative, rod-shaped, pale-pink pigmented cells can optimal grow at $23^{\circ} \mathrm{C}$, but grows well down to $10^{\circ} \mathrm{C}$ (Wartiainen et al. 2006a). Cells of Methylocystis rosea are gram-negative, pink-red pigmented, polymorphic rods belong to type II species. Organisms can grow between 5 and $37^{\circ} \mathrm{C}$ with optimal growth at $27^{\circ} \mathrm{C}$ (Wartiainen et al. 2006b).

Recently the biodiversity in cryopegs (100,000-120,000 years old) in Siberian permafrost was described (Gilichinsky et al. 2005). Direct microbial cell counts revealed numbers in the range of $10^{7}$ cells $\mathrm{ml}^{-1}$ saline water. A variety of aerobic and anaerobic, spore-less and spore-forming, halophilic and psychrophilic bacteria as well as mycelial fungi and yeast have been isolated including genera like Arthrobacter, Bacillus, Erwinia, Frigoribacterium, Microbacterium, Psychrobacter, Paenibacillus, Rhodococcus and Subtercola. Clostridium algoriphilum sp. nov. was isolated, which is adapted to low nutrient concentrations (Fig. 7.4e; Shcherbakova et al. 2005). The metabolic end product of this anaerobic bacterium is lactate and butyrate, which can be used as substrate by heterotrophic Psychrobacter isolates, indicating the possibility of a trophic food chain within the microbial communities of cryopegs.

There are some further new microorganisms, which were isolated recently from different habitats as for example: Acetobacterium tundrae (DSM 9173) was isolated from tundra wetlands of Polar Ural (Simankova et al. 2000). The organisms 
is cold-adapted with an optimum of grows at $20^{\circ} \mathrm{C}$ (range between $1-30^{\circ} \mathrm{C}$ ). Cells were gram-positive, oval shaped, flagellated rods (Fig. 7.4d), which fermented $\mathrm{H}_{2} / \mathrm{CO}_{2}$, formate, methanol and several sugars to acetate as the sole end product. Carnobacterium pleistocenium, a novel psychrotolerant, facultative anaerobe bacterium, was isolated from Pleistocene ice from the Fox tunnel in Alaska (Pikuta et al. 2005). The organism is characterized by gram-positive, motile, rod-shaped cells, which can optimal grow at $24^{\circ} \mathrm{C}$ (range $0-28^{\circ} \mathrm{C}$ ). Metabolic end products are acetate, ethanol and $\mathrm{CO}_{2}$. Exiguobacterium sp. 255-15 is a non-spore forming gram-positive bacterium isolated from a 2-3 million-year permafrost core (Vishnivetskaya et al. 2000). The cells are short rods about $1 \mu \mathrm{m}$ in length with rounded ends. They are facultative anaerobes but grow more profusely aerobically. A novel nitrite oxidizing bacterium enriched and provisional classified as "Candidatus Nitrotoga arctica" (Fig. 7.4a). The organism was cultured at $10^{\circ} \mathrm{C}$ and is characterized by a fatty acid profile, which is different from those of known nitrite oxidizers but similar to fatty acid profiles of $\beta$-Proteobacteria (Alawi et al. 2007). Psychrobacter sp. 273-4 is a small, nonmotile coccoid rod (Fig. 7.4f) often found in pairs isolated from a 20-40 thousandyear-old Siberian permafrost core (Vishnivetskaya et al. 2000). The strain is characterized by rapid growth at low temperatures and excellent survival after exposure to long-term freezing.

Viable green algae were isolated from Arctic deep sediments frozen for 5-7 thousand years (Vorobyova et al. 1997). All isolates grew at a low rate at $20-25^{\circ} \mathrm{C}$ and were sensitive to high light intensities. Photosynthetic pigments, chlorophyll $a$, chlorophyll $b$, and pheophytin were found in a wide range of sediments of different genesis and age.

Both in the active layer and in the perennially frozen sediments a large variety of fungi was determined. In the active layer of Arctic tundra tussock and shrub soils the fungal community was composed of Ascomycota, Basidiomycota, Zygomycota, Chytridiomycota, Glomeromycota and Euryota (Wallenstein et al. 2007). While the tussock communities had higher proportions of Ascomycota (Dothideomycetes, Pezizomycetes and Sordariomycetes), the shrub soils were dominated by Zygomycota (Zygomycetes). Another study performed in Alaska reported the dominance of basidiomycetous dimorphic yeasts (Mrakia and Leucosporidium) and ascomycetous mycelial fungi Geomyces (Panikov and Sizova 2007). In permafrost deposits of up to an age of 400 ky only the major groups Ascomycota, Basidiomycota and Zygomycota could be verified (Lydolph et al. 2005).

The absence of a wide spectrum of cultured organisms suggests that many microorganisms from permafrost environments are either unculturable or the appropriate methods of enrichment and cultivation have not been attempted. 


\subsection{Role and Significance}

Certain key processes of global biogeochemical cycles (e.g. C, N, S) are carried out exclusively by highly specialized microorganisms (e.g. methanogenic archaea, acetogenic, nitrifying and sulfate-reducing bacteria), which play the quantitatively dominant role in mineralization processes (Hedderich and Whitman 2006, Drake et al. 2006, Bock and Wagner 2006, Rabus et al. 2006). Although the physiology and ecology of many microorganisms from different environments is well studied, little is known about the activity and function of many of the phyla and species in permafrost habitats described in the previous section.

The active layer of permafrost is subjected to freezing and thawing cycles during the year showing large gradients in temperature and geochemistry along the depth profiles of the soils. The extreme temperature regime is one of the most important parameter regulating the metabolic activity and survival of microorganisms. Several recent studies demonstrated activities of microorganisms from the active layer and the perennially frozen ground at sub-zero temperatures. Metabolic activities down to $-10^{\circ} \mathrm{C}$ of different microorganisms isolated from Siberian permafrost were reported by Bakermans et al. (2003) and Jakosky et al. (2003). The incorporation of ${ }^{14} \mathrm{C}$-labeled acetate into bacterial lipids determined in microcosm experiments at temperatures between $+5^{\circ} \mathrm{C}$ to $-20^{\circ} \mathrm{C}$ showed activity of the indigenous microorganisms (Rivkina et al. 2000). The minimum temperature for growth of microorganisms was recently reported with $-35^{\circ} \mathrm{C}$ (Panikov and Sizova 2007). The isolated microorganisms were able to grow down to $-17^{\circ} \mathrm{C}$ with rates similar to growth above the freezing point. Between $-18^{\circ} \mathrm{C}$ to $-35^{\circ} \mathrm{C}$ growth was only detectable for three weeks after cooling. Then metabolic activity declined to zero, and microorganisms entered a state of reversible dormancy. Studies on methanogenic activity and biomass in a Holocene permafrost core from the Lena Delta (Siberia) showed that the methane found in certain depth of the sediments originated from modern methanogenesis by cold-adapted methanogenic archaea (Wagner et al. 2007). These findings are in accordance with the microbial metabolic rates of coldadapted microorganisms proposed by Price and Sowers (2004): the first group of microorganisms is characterized by a rate sufficient for microbial growth; the second group has a rate sufficient for metabolism but too low for growth and the third one shows a rate sufficient for survival, in which they can repair macromolecular damage, but are probably largely dormant. The reviewed results of microbial metabolism at sub-zero temperatures contradict the idea of the 'community of survivors' in permafrost soils (Gounot 1999, Rothschild and Mancinelli 2001), which are not thought to 'prefer' their environment but are said to be rather more resistant than others that have endured a similar fate.

Currently most strongly discussed with reference to permafrost ecosystems is the question: "What happens to the carbon stored in permafrost in consequence of a 
climate change?" The relevance of Arctic carbon reservoirs is highlighted by current climate models that predict significant changes in temperature and precipitation in the northern hemisphere (Kattenberg et al. 1996, Smith et al. 2002). Particularly, the degradation of permafrost and the associated release of climate relevant trace gases from intensified microbial turnover of organic carbon and from destabilized gas hydrates represent a potential environmental hazard.

The carbon mineralization under anoxic conditions within the predominantly wet permafrost soils is mainly performed via methane production, which is the final process in a sequence of hydrolysis and fermentation (Schink and Stams 2006). Thus, methanogenic archaea are standing in close relationship with other microorganisms of the anaerobic food chain (e.g. acetogenic bacteria or clostridia; Kotsyurbenko et al. 1993, Stams 1994). In cold environments two main pathways of energy-metabolism by methanogens dominate: (i) the reduction of $\mathrm{CO}_{2}$ to $\mathrm{CH}_{4}$ using $\mathrm{H}_{2}$ as a reductant (hydrogenotrophic methanogenesis) and (ii) the fermentation of acetate to $\mathrm{CH}_{4}$ and $\mathrm{CO}_{2}$ (acetoclastic methanogenesis; Conrad 2005).

Methanogenic activity was observed at low in situ temperatures with rates up to $39 \mathrm{nmol} \mathrm{CH}_{4} \mathrm{~h}^{-1} \mathrm{~g}^{-1}$ soil in the active layer of permafrost (Wagner et al. 2003, Høj et al. 2005, Metje and Frenzel 2007). The highest activities were measured in some extent in the coldest zones of the profiles. Furthermore, it could be shown that the methane production is regulated more by the quality of soil organic carbon than by the in situ temperature (Wagner et al. 2005, Ganzert et al. 2007). Another important factor affecting archaeal communities in permafrost soils is the water regime. Along a natural soil moisture gradient, changes in archaeal community composition were observed, which suggest that the differences in these communities were responsible for the large-scale variations in methane emissions (Høj et al. 2006).

The microbial methane oxidation in the oxic zones of the active layer has great importance for the control of methane releases from permafrost environments. Methane oxidizing bacteria are using methane as the sole carbon source, while energy is gained by the oxidation of $\mathrm{CH}_{4}$ to $\mathrm{CO}_{2}$ (Hanson and Hanson 1996). The methane oxidation rates in permafrost-affected Canadian soils ranged between 58 and $92 \%$ depending on the environmental conditions (Popp et al. 2000). However, the methane oxidation activities showed vertical shifts within the optimal temperature and within the distribution of type I and type II methanotrophs in Siberian permafrost soils (Liebner and Wagner 2007). In the upper active layer, maximum methane oxidation potentials were detected at $21^{\circ} \mathrm{C}$. Deep active layer zones that are constantly exposed to temperatures below $2^{\circ} \mathrm{C}$ showed a maximum potential for methane oxidation at $4^{\circ} \mathrm{C}$. This indicates a dominance of psychrophilic methanotrophs close to the permafrost table.

The results demonstrate the close relationship between methane fluxes and the fundamental microbiological processes and communities in permafrost soils. The microorganisms do not only survive in their extreme habitat but also can be metabolic 
active under in situ conditions, which shows that the microbial communities are well adapted to low temperatures and extreme geochemical gradients. However, they are also able to follow an increasing temperature over a wide range. This is in accordance with reported results showing that a slight increase of the temperature can lead to a substantial increase in methanogenic activity within perennially frozen deposits (Wagner et al. 2007). In case of permafrost degradation by thermokarst or coastal erosion processes, this would lead to an extensive expansion of the methane deposits and fluxes with their subsequent impacts on the total atmospheric methane budget.

The nitrogen turnover is strongly correlated with the carbon cycle but little is known about nitrogen fluxes in Arctic ecosystems and the responsible organisms. Low temperature and poor substrate quality often limit decomposition and nitrogen mineralization in many arctic ecosystems (Jonasson et al. 1993). However, higher rates of nitrogen fixation were observed in climate change simulation experiments on Ellesmere Island, Canada (Deslippe et al. 2005). Nitrifying bacteria were detected in permafrost soils and sediments (Bartosch et al. 2002, Alawi et al. 2007). Even in old deep permafrost sediments, nitrifyers can survive long periods of starvation and dryness (Soina et al. 1991). Nearly nothing is known about the Arctic source strength for the long-life greenhouse gases $\mathrm{NO}$ and $\mathrm{N}_{2} \mathrm{O}$. Furthermore, the interaction of climate relevant processes like microbial methane oxidation is influenced by the activity of ammonia oxidizers. The Artic carbon fluxes and turnover times are limited by the microbial mediated nitrogen mineralization.

Sulphur plays a key role in marine biogeochemical cycles, in particular in anaerobic sediments of the marine shelf. About $50 \%$ of the carbon mineralization in shelf sediments is oxidized via the reduction of sulphate to sulphide by sulphate reducing bacteria (Jørgensen 1982). The released sulphide can be oxidized chemically or by sulphide oxidizing bacteria in aerobic sediment layers. However, coastal erosion and sea level rise created the shallow shelfs of the Arctic Ocean as for example those of the Laptev Sea whose bottom is formed by the formerly terrestrial permafrost (Rachold et al. 2005, Romanovskii et al. 2005). Flooding of the cold $\left(-5\right.$ to $\left.-15^{\circ} \mathrm{C}\right)$ terrestrial permafrost with relatively warm $\left(-0.5\right.$ to $\left.-2^{\circ} \mathrm{C}\right)$ saline, sulphur-rich water from the Laptev Sea changed the system profoundly and resulted in a warming of the permafrost (Rachold et al. 2007). Studies on the microbial diversity and activity in submarine permafrost neither have been conducted by cultivation dependent methods nor by cultivation independent molecular approaches. Therefore, the significance of microbial mineralization and response to rising temperatures in these carbon rich permafrost ecosystem, as well as microbial abundance and diversity is totally unknown.

The permafrost environment forces the adaptation of the microbial communities to low temperature conditions with species, which have been untraced in temperate ecosystems so far. Therefore, Arctic permafrost environments can be 
seen as active microbial ecosystems rather than frozen habitats with microbial survivors. The evaluation of microbiological data and their correlation with climatic and geochemical results represents the basis for the understanding of the role of permafrost in the global system, in particular feedback mechanisms related to nutrient cycles, biogeochemical processes and greenhouse gas emissions in the scope of a warming Earth.

\subsection{Future Direction of Research}

Although one fourth of the Earth land surface and distinct areas of the coastal sea shelfs are affected by permafrost the physiology, function and diversity of microbial communities in these ecosystems is sparsely investigated so far. This may be partially caused by the accessibility of the investigation areas and the associated logistic problems. However, the larger problem seems to be the development of novel methodologies specific for permafrost sampling and isolation of cold-adapted microorganisms from Arctic soils and sediments. This is shown in the discrepancy between the small numbers of psychrophilic microorganism isolated so far from permafrost environments in contrast to the observed significant metabolic rates under in situ conditions. Methodical developments should consider the following aspects: enrichment of microorganisms should be performed directly in the field or in batch or continuous laboratory culture; culture techniques for the enrichment of 'syntrophically associated' microorganisms; the need of sub-zero culturing methods; and state-ofthe-art culture-independent molecular techniques for diversity and functional analyses of microbial communities should be applied on permafrost.

The lack of isolates from permafrost affects also a possible biotechnological use. Cold-adapted microorganisms from permafrost exhibit properties distinctly different from other thermal classes. Therefore, the vast genetic resources of microorganisms from permafrost environments are nearly unexploited. It is likely that mainly extremophilic microbes could offer technologically and/or economically significant compounds such as enzymes, polysaccharides, osmoprotectors and liposomes (Cavicchioli et al., 2002). Therefore, by exploring microbial diversity in cold regions, one future goal will be to get new isolates in hand, which might be important for biotechnology processes or medicine.

Apart from the global relevance of permafrost as a large carbon reservoir, this extreme environment is also of particular interest in the scope of astrobiological research as an analogue for extraterrestrial permafrost habitats, which is a common phenomenon in our solar system (Gilichinsky 2001, Wagner et al. 2001). Particularly, the observation of methane in the Martian atmosphere by the current mission of the European Space Agency (ESA, Formisano 2004) Mars Express has stimulated the debate over possible microbial life on Mars. Currently, it was shown that 
methanogenic archaea isolated from Siberian permafrost environments are more tolerant against environmental stress and simulated thermo-physical Martian conditions than methanogens from temperate ecosystems (Morozova and Wagner 2007, Morozova et al. 2007). To obtain a proper understanding of potential microbial life in extraterrestrial permafrost ecosystems microorganisms from terrestrial permafrost are considered as model organisms to study the survival under extreme living conditions and the molecular mechanisms of permafrost extremophiles.

\subsection{References}

Alawi M, Lipski A, Sanders T, Pfeiffer E.-M, Spieck E (2007) Cultivation of a novel cold-adapted nitrite oxidizing Betaproteobacterium from the Siberian Arctic. The ISME Journal, doi $0.1038 /$ sj.ismej.9800029

Ananyan AA (1970) Unfrozen water content in frozen clay at a temperature from $-0.6^{\circ} \mathrm{C}$ to $-40^{\circ} \mathrm{C}$ $-60^{\circ} \mathrm{C}$. Merzlotnye Issledovaniya 10:267-270 (in Russian)

Bakermans C, Tsapin Al, Souza-Egipsy V, Gilichinsky DA, Nealson KH (2003) Reproduction and metabolism at $-10^{\circ} \mathrm{C}$ of bacteria isolated from Siberian permafrost. Environ Microbiol 5: 321-326

Bartosch S, Hartwig C, Spieck E, Bock E (2002) Immunological detection of Nitrospira-like bacteria in various soils. Microbiol Ecol 43:26-33

Bock E, Wagner M (2006) Oxidation of inorganic nitrogen compounds as an energy source. In: Dworkin M, Falkow S, Rosenberg E, Schleifer K-H, Stackebrandt E (eds.) Prokaryotes, vol 2, Springer, New York, pp 457-495

Bockheim JG, Everett LR, Hinkel KM, Nelson FE, Brown J (1999) Soil organic storage and distribution in Arctic Tundra, Barrow, Alaska. Soil Sci Soc Am J 63:934-940

Boyd WL (1958) Microbiological studies of arctic soils. Ecol 39:332-336

Boyd WL and Boyd JW (1964) The presence of bacteria in permafrost of the Alaskan arctic. Can J Microbiol 10:917-919

Cavicchioli R, Siddiqui KS, Andrews D, Sowers KR (2002) Low-temperature extremophiles and their applications. Curr Opin Biotech 13:253-261

Colwell FS, Delwiche ME, Blackwelder D, Wilson MS, Lehman RM, Uchida T (1999) Microbial communities from core intervals, JAPEX/JNOC/GSC Mallik 5L-38 gas hydrate research well. In: Scientific Results from Mallik 2002 Gas Hydrate Production Research Well Program, Mackenzie Delta, Northwest Territories, Canada. Dallimore SR, Uchida T, Collett TS(eds), Bulletin 544. Geological Survey of Canada, Microbiology section, pp. 189-195

Conrad R (2005) Quantification of methanogenic pathways using stable carbonisotopic signatures: a review and a proposal. Organ Geochem 36:739-752

Deslippe JR, Egger KN, Henry HR (2005) Impact of warming and fertilization on nitrogen-fixing microbial communities in the Canadian High Arctic. FEMS Microbiol Ecol 53:41-50

Drake H, Küsel K, Matthies C (2006) Acetogenic prokaryotes. In: Dworkin M, Falkow S, Rosenberg E, Schleifer K-H, Stackebrandt E (eds.) Prokaryotes, vol 2, Springer, New York, pp 354-420

Formisano V (2004) Detection of methane in the atmosphere of Mars. Science 306:1758-1761

French HM (1996) The Periglacial Environment, Longman, London

Ganzert L, Jurgens G, Münster U and Wagner D (2007) Methanogenic communities in permafrostaffected soils of the Laptev Sea coast, Siberian Arctic, characterized by $16 \mathrm{~S}$ rRNA gene fingerprints. FEMS Microbiol Ecol 59:476-488

Garcia JL, Patel BKC and Olliver B (2000) Taxonomic, phylogenetic and ecological diversity of methanogenic archaea. Anaerobe 6:205-226

Gilichinsky DA and Wagener S (1994) Microbial life in permafrost. In: Gilichinsky D (ed) Viable microorganisms in Permafrost, Pushchino Research Cener, pp. 7-20

Gilichinsky DA, Wagener S, Vishnivetskaya TA (1995) Permafrost microbiology. Permafrost Periglac Process 6:281-291

Gilichinsky DA (2002) Permafrost model of extraterrestrial habitat. In: Horneck G, Baumstark-Khan C (eds) Springer, Berlin, pp. 271-295

Gilichinsky DA, Rivkina E, Bakermans C, Shcherbakova V, Petrovskaya L, Ozerskaya S, Ivanushkina N, Kochkina G, Laurinavichuis K, Pecheritsina S, Fattakhova R, Tiedje JM (2005) Biodiversity of cryopegs in permafrost. FEMS Microbiol. Ecol 53:117-128 
Gounot AM (1999) Microbial life in permanently cold soils. In: Margesin R, Schinner F(eds) Coldadapted organisms, Springer, Berlin, pp. 3-16

Grosskopf R, Stubner S, Liesack W (1998) Novel euryarchaeotal lineages detected on rice roots and in the anoxic bulk soil of flooded rice microcosms. Appl Environ Microbiol 64:4983-4989

Hales BA, Edwards C, Ritchie DA, Hall G, Pickup RW, Saunders JR (1996) Isolation and identification of methanogen-specific DNA from blanket bog peat by PCR amplification and sequence analysis. Appl Environ Microbiol 62:668-675

Hanson RS, Hanson TE (1996) Methanotrophic bacteria. Microbiol Rev 60:439-471

Hedderich R, Whitman W (2006) Physiology and biochemistry of the methane-producing archaea. In: Dworkin M, Falkow S, Rosenberg E, Schleifer K-H, Stackebrandt E (eds.) Prokaryotes, vol 2, Springer, New York, pp 1050-1079

Høj L, Olsen RA, Torsvik VL (2005) Archaeal communities in High Arctic wetlands at Spitsbergen, Norway $\left(78^{\circ} \mathrm{N}\right)$ as characterised by $16 \mathrm{~S}$ rRNA gene fingerprinting. FEMS Microbiol Ecol 53:89-101

Høj L, Rusten M, Haugen LE, Olsen RA, Torsvik VL (2006) Effects of water regime on archaeal community composition in Arctic soils. Environ. Microbiol 8: 984-996

International Permafrost Association Standing Committee on Data Information and Communication (comp.). 2003. Circumpolar Active-Layer Permafrost System, Version 2.0. Edited by M. Parsons and T. Zhang. Boulder, CO: National Snow and Ice Data Center/World Data Center for Glaciology. CD-ROM

Jakosky BM, Nealson KN, Bakermans C, Ley RE, Mellon MT (2003) Subfreezing activity of microorganisms and the potential habilitability of Mars' polar regions. Astrobiology 3:343-350

James N, Sutherland ML (1942) Are there living bacteria in permanently frozen subsoil? Can J Res Sect Bot Sci 20:228-235

Jonasson S, Havstrom M, Jensen M, Callaghan TV (1993) In situ mineralization of nitrogen and phosphorus of arctic soils after perturbations simulating climate-change. Oecologia 95: 179-186

Jørgensen BB (1982) Mineralization of organic matter in the sea bed - the role of sulphate reduction. Nature 296:643-645

Kattenberg A, Giorgi F, Grassel H, Meehl GA, Michell JFB, Stoufer RJ, Tokioka T, Weaver AJ, Wigley TML (1996) Climate models - projections of future climate. In: Houghton JT (ed) Climate Change 1995, University Press, Cambridge, pp 285-357

Khlebnikova GM, Gilichinsky DA, Fedorov-Davydov DC, Vorobyova EA (1990) Quantitative evaluation of microorganisms in permafrost deposits and buried soils. Microbiology 59:106-112

Kobabe S, Wagner D, Pfeiffer EM (2004) Characterization of microbial community composition of a Siberian tundra soil by fluorescence in situ hybridization. FEMS Microbiol Ecol 50:13-23

Kotsyurbenko OR, Nozhevnikova AN, Zavarzin GA (1993) Methanogenic degradation of organic matter by anaerobic bacteria at low temperature. Chemosphere 27:1745-1761

Kotsyurbenko OR, Simankova MV, Nozhevnikova AN, Zhilina TN, Bolotina NP, Lysenko AM, Osipov GA (1995) New species of psychrophilic acetogens: Acetobacterium bakii sp. nov., A. paludosum sp. nov., A. fimetarium sp. nov. Arch Microbiol 163:29-34

Kris AE (1940) Microorganisms in permafrost. Microbiology 9:879-886 (in Russian)

Liebner S, Wagner D (2007) Abundance, distribution and potential activity of methane oxidising bacteria in permafrost soils from the Lena Delta, Siberia. Environ Microbiol 9:107-117

Lydolph MC, Jacobsen J, Arctander P, Thomas M, Gilbert P, Gilichinsky DA, Hansen AJ, Willerslev E, Lange $L$ (2005) Beringian paleoecology inferred from permafrost-preserved fungal DNA. Appl Environ Microbiol 71:1012-1017

Melloh RA, Crill PM (1996) Winter methane dynamics in a temperate peatland. Global Biogeochem Cyc 10:247-254

Metje M, Frenzel P (2007) Methanogenesis and methanogenic pathways in a peat from subarctic permafrost. Environ Microbiol 9:954-964

Morozova D, Möhlmann D, Wagner D (2006) Survival of methanogenic archaea from Siberian permafrost under simulated Martian thermal conditions. Orig Life Evol Biosph 37:189-200

Morozova D, Wagner D (2007) Stress response of methanogenic archaea from Siberian permafrost compared to methanogens from non-permafrost habitats. FEMS Microbiol Ecol 61:16-25

Neufeld JD, Mohn WW (2005) Unexpectedly high bacterial diversity in Arctic tundra relative to boreal forest soils, revealed by serial analysis of ribosomal sequence tags. Appl. Environ Microbiol 71:5710-5718

Nolan M, Brigham-Grette J (2007) Basic hydrology, limnology, and meteorology of modern Lake El'gygytgyn, Siberia. J Paleolimnol 37:17-35

Ochsenreiter T, Selezi D, Quaiser A, Bonch-Osmolovskaya L, Schleper C (2003) Diversity and abundance of Crenarchaeota in terrestrial habitats studied by 16S RNA surveys and real time PCR. Environ Microbiol 5:787-797 
Omelyansky VL (1911) Bacteriological investigation of the Sanga mammoth and surrounding soil. Arkhiv Biologicheskikh Nauk (Scientific Biological Archive) 16: 335-340 (in Russian).

Omelchenko MB, Vasilieva LV, Zavarzin GA, Savel'eva ND, Lysenko AM, Mityushina LL, Khmelenina VN, Trotsenko YA (1996) A novel psychrophilic methanotroph of the genus Methylobacter. Microbiology 65:339-343

Orvig S (1970) Climates of the polar regions. World Survey of Climatology. Elsevier, New York

Ostroumov V, Siegert C (1996) Exobiological aspects of mass transfer in microzones of permafrost deposits. Adv Space Res 18:79-86

Ostroumov V (2004) Physico-chemical processes in cryogenic soils. In: Kimble JM (ed) Cryosols, Springer, Berlin, pp 347-364

Overduin P (2007) The expedition COAST I. In: Schirrmeister L. (ed.) Expeditions in Siberia in 2005. Russian-German Cooperation System Laptev Sea. Reports on Polar Research 550:1-39

Panikov NS, Sizova MV (2007) Growth kinetics of microorganisms isolated from Alaskan soil and permafrost in solid media frozen down to $-35^{\circ} \mathrm{C}$. FEMS Microbiol Ecol 59:500-512

Pikuta EV, Marsic D, Bej A, Tang J, Krader P, Hoover RB (2005) Carnobacterium pleistocenium sp. nov., a novel psychrotolerant, facultative anaerobic bacterium isolated from permafrost of the Fox tunnel in Alaska. Int J Syst Evol Microbiol 55:473-478

Popp TJ, Chanton JP, Whiting GJ, Grant N (2000) Evaluation of methane oxidation in the rhizosphere of a Carex dominated fen in north central Alberta, Canada. Biogeochem 51:259-281

Price PB, Sowers T (2004) Temperature dependence of metabolic rates for microbial growth, maintenance, and survival. Proc Natl Acad Sci 101:4631-4636

Rabus R, Hansen T, Widdel F (2006) Dissimilatory sulfate- and sulfur-reducing prokaryotes. In: Dworkin M, Falkow S, Rosenberg E, Schleifer K-H, Stackebrandt E (eds.) Prokaryotes, vol 2, Springer, New York, pp 659-768

Rachold V, Are FE, Atkinson DE, Cherkashov G, Solomon SM (2005) Arctic Coastal Dynamics (ACD): an introduction. Geo-Marine Lett 25:63-68

Rachold V, Bolshiyanov DY, Grigoriev MN, Hubberten HW, Junkers R, Kunitsky VV, Merker F, Overduin P, Schneider W (2007) Nearshore Arctic subsea permafrost in transition. EOS 88:149150

Ramakrishnan B, Lueders T, Dunfield PF, Conrad R, Friedrich MW (2001) Archaeal community structures in rice soils from different geographical regions before and after initiation of methane production. FEMS Microbiol Ecol 37:175-186

Rivkina, EM, Gilichinsky, D., Wagener, S., Tiedje, J. and McGrath, J.: 1998, Biochemical activity of anaerobic microorganisms from buried permafrost sediments, Geomicrobiol 15:187-193

Rivkina EM, Friedmann EI, McKay CP, Gilichinsky DA (2000) Metabolic activity of permafrost bacteria below the freezing point. Appl Environ Microbiol 66:3230-3233

Rivkina E, Laurinavichius K, McGrath J, Tiedje J, Shcherbakova V, Gilichinsky D (2004) Microbial life in permafrost. Adv Space Res 33:1215-1221

Romanovskii NN, Hubberten H-W, Gavrilov AV, Eliseeva AA, Tipenko GS (2005) Offshore permafrost and gas hydrate stability zone on the shelf of East Siberian Seas. Geo-Marine Lett 25:167-182

ROSHYDROMET (2004) Russian Federal Service for Hydrometeorology and Environmental Monitoring, http://www.worldweather.org/107/c01040.htm

Rothschild LJ, Mancinelli RL (2001) Life in extreme environments. Nature 409:1092-1101

Šantrǔčková H, Bird MI, Kalaschnikov YN, Grund M, Elhottova D, Šimek M, Grigoryev S, Gleixner G, Arneth A, Schulze E-D, Lloyd J (2003) Microbial characteristics of soils on a latitudinal transect in Siberia. Global Change Biol 9:1106-1117

Schink B, Stams AJM (2006) Syntrophism among Prokaryotes. In: Dworkin M, Falkow S, Rosenberg E, Schleifer K-H, Stackebrandt E (eds.) Prokaryotes, vol 2, Springer, New York, pp 309-335

Shcherbakova VA, Chuvilskaya NA, Rivkina EM, Pecheritsyna SA, Laurinavichius KS, Suzina NE, Osipov GA, Lysenko AM, Gilichinsky DA, Akimenko VK (2005) Novel psychrophilic anaerobic spore-forming bacterium from the overcooled water brine in permafrost: description Clostridium algoriphilum sp. nov. Extremophiles 9:239-246

Shi T, Reevers R, Gilichinsky D, Friedmann El (1997) Characterization of viable bacteria from Siberian permafrost by $16 \mathrm{~S}$ rDNA sequencing. Microbial Ecol 33:167-179

Simankova MV, Kotsyurbenko OR, Stackebrandt E, Kostrikina NA, Lysenko AM, Osipov GA, Nozhevnikova AN (2000) Acetobacterium tundrae sp. nov., a new psychrophilic acetogenic bacterium from tundra soil. Arch Microbiol 174:440-447

Smith J, Stone R, Fahrenkamp-Uppenbrink J (2002) Trouble in polar paradise: Polar science. Science 297:1489-1492

Soina VS, Lebedeva EV, Golyshina OV, Fedorov-Davydov DG, Gilichinsky DA (1991) Nitrifying bacteria from permafrost deposits of the Kolyma lowland. Microbiologia 60:187-190 (in Russian) 
Spirina EV, Fedorov-Davydov DG (1998) Microbiological characterization of cryogenic soils in the Kolymskaya Lowland. Eurasian Soil Sci 31:1331-1344

Stams AJM (1994) Metabolic interactions between anaerobic bacteria in methanogenic environments. Antonie van Leeuwenhoek 66:271-294

Steven B, Briggs G, McKay CP, Pollard WH, Greer CW, Whyte LG (2007) Characterization of the microbial diversity in a permafrost sample from the Canadian high Arctic using culture-dependent and culture-independent methods. FEMS Microbiol Ecol 59:513-523

Suzuki T, Nakayama T, Kurihara T, Nishino T, Esaki N (2001) Cold-active lipolytic activity of psychrotrophic Acinetobacter sp. strain no. 6. J Biosci Bioeng 92:144-148

Trotsenko YA, Khmelenina VN (2005) Aerobic methanotrophic bacteria of cold ecosystems. FEMS Microbiol Ecol 53:15-26

Van Everdingen R (2005) Multi-language glossary of permafrost and related ground-ice terms. National Snow and Ice Data Center/World Data Center for Glaciology. Boulder, Colorado, USA

Van Vliet-Lanoë B. (1991) Differential frost heave, load casting and convection: converging mechanisms; a discussion of the origin of cryoturbations. Permafrost Periglac Process 2:123-139

Vishnivetskaya T, Kathariou S, McGrath J, Gilichinsky D, Tiedje J (2000) Low-temperature recovery strategies for the isolation of bacteria from ancient permafrost sediments. Extremophiles 4:165-173

Vishnivetskaya TA, Petrova MA, Urbance J, Ponder M, Moyer CL, Gilichinsky DA, Tiedje JM (2006) Bacterial community in ancient Siberian permafrost as characterized by culture and cultureindependent methods. Astrobiology 6:400-414

Vorobyova E, Soina V, Gorlenko M, Minkovskaya N, Zalinova N, Mamukelashvih A, Gilichinsky D, Rivkina E, Vishnivetskaya T (1997) The deep cold biosphere: facts and hypothesis. FEMS Microbiol Rev 20:277-290

Wagner D, Spieck E, Bock E, Pfeiffer EM (2001) Microbial life in terrestrial permafrost: methanogenesis and nitrification in Gelisols as potentials for exobiological processes. In: Horneck G, Baumstark-Khan C (eds) Astrobiology: The quest for the conditions of life. Springer. Berlin, pp143-159

Wagner D, Kobabe S, Pfeiffer EM, Hubberten HW (2003) Microbial controls on methane fluxes from a polygonal tundra of the Lena Delta, Siberia. Permafrost Periglac Process 14:173-185

Wagner D, Lipski A, Embacher A, Gattinger A (2005) Methane fluxes in permafrost habitats of the Lena Delta: effects of microbial community structure and organic matter quality. Environ Microbiol 7:1582-1592

Wagner D, Gattinger A, Embacher A, Pfeiffer EM, Schloter M, Lipski A (2007) Methanogenic activity and biomass in Holocene permafrost deposits of the Lena Delta, Siberian Arctic and its implication for the global methane budget, Global Change Biol 13:1089-1099

Wallenstein MD, McMahon S, Schimel J (2007) Bacterial and fungal community structure in Arctic tundra tussock and shrub soils. FEMS Microbiol Ecol 59:428-435

Wartiainen I, Hestnes AG, Svenning MM (2003) Methanotrophic diversity in high arctic wetlands on the islands of Svalbard (Norway) - denaturing gradient gel electrophoresis analysis of soil DNA and enrichment cultures. Can J Microbiol 49:602-612

Wartiainen I, Hestnes AG, McDonald IR, Svenning MM (2006a) Methylocystis rosea sp. nov., a novel methanotrophic bacterium from Arctic wetland soil, Svalbard, Norway $\left(78^{\circ} \mathrm{N}\right)$. Int J Sys Evol Microbiol 56:541-547

Wartiainen I, Hestnes AG, McDonald IR, Svenning MM (2006b) Methylobacter tundripaludum sp. nov., a methane-oxidizing bacterium from Arctic wetland soil on the Svalbard islands, Norway $\left(78^{\circ} \mathrm{N}\right)$. Int J Sys Evol Microbiol 56:109-113

Washburn AL (1978) Geocryology. A survey of periglacial processes and environments. Arnold, London

Williams PJ, Smith MW (1989) The frozen earth: fundamentals of geocryology. Cambridge University Press, Cambridge

Yershov ED (1998) General geochryology. Cambridge University Press, Cambridge

Zak DR, Kling GW (2006) Microbial community composition and function across an arctic tundra landscape. Ecology 87:1659-1670

Zhang T, Barry RG, Knowles K, Heginbotton JA, Brown J (1999) Statistics and characteristics of permafrost and ground-ice distribution in the northern hemisphere. Polar Geography 23:132-154

Zhou J, Davey ME, Figueras JB, Rivkina E, Gilichinsky D, Tiedje JM (1997) Phylogenetic diversity of a bacterial community determined from Siberian tundra soil DNA. Microbiology 143:3913-3919

Zimov SA, Schuur EAG, Chapin III FS (2006) Permafrost and the global carbon budget. Science 312:1612-1613

Zvyagintsev DG, Gilichinsky DA, Blagodatskii SA, Vorobyeva EA, Khlenikovam GM, Arkhangelov AA, Kudryavtseva NN (1985) Survival time of microorganisms in permanently frozen sedimentary rock and buried soils. Microbiology 54:155-161 